\title{
STUDY OF THE POSSIBILITY OF DISTILLATION OF TECHNETIUM FROM MOLYBDENUM SOLUTIONS ON EXAMPLE OF RHENIUM
}

\author{
O. I. Azarov, V. O.Bocharov, O.F.Stoyanov \\ National Science Center "Kharkiv Institute of Physics and Technology", 61108 Kharkiv, Ukraine
}

(Received January 21, 2019)

\begin{abstract}
To study the processes of separation of molybdenum and technetium, rhenium, which has chemical properties close
\end{abstract} to technetium, is used. It is rational to divide molybdenum and technetium through distillation.

PACS: $8255 .+\mathrm{e}$

\section{INTRODUCTION}

To date, in the field of nuclear medicine technetium$99 \mathrm{~m}$ is most often used as a radiopharmaceutical. It has a half-life of 6.02 hours [1] and is suitable for scanning of the thyroid and salivary glands, the brain, the heart and blood vessels. Rhenium is a chemical analogue of technetium and can replace it in experiments on the separation of technetium.

\section{WAYS OF TECHNETIUM OBTAINING}

There is a chronic shortage of technetium in the world. Technetium is made up of molybdenum-99, which is most often produced in an atomic reactor made of molybdenum- 98 by the reaction of the neutron joining. In uranium fission products, $3 \ldots 6 \%$ of molybdenum-99 is present, because its allocation is associated with enormous difficulties due to the very high activity of the mixture and its complicated elemental composition. Further, the radioactive molybdenum, decaying with a half-life of 66 hours, gives technetium- $99 \mathrm{~m}$. There are also other means of producing molybdenum-99 [2], one of which is photonuclear using an electronic accelerator to irradiate targets from molybdenum-100 gamma quanta. At the same time, from the nuclei of the molybdenum-100, the neutron is pulled out, and thus a molybdenum99 is produced. Assume that the use of electronic accelerators will help to reduce the cost of production technetium and reduce the amount of radioactive waste $[3,4]$.

Another important task is to isolate technetium from the molybdenum matrix. Laboratory devices for the separation of molybdenum and technetium (the so-called technetium generators) are based on different sorption capabilities of their inorganic compounds or on different extraction properties. For generators of the first type, oxides and hydroxides of metals $(A l, T i, Z r)$ as well as selective (chelated) ionites are used.
Extraction generators have greater efficiency and allow the use of low-level initial material, which involves methylethylketone (MEK) as a solvent and reagent. Although technetium generators are not very complex devices, we have the opportunity to further simplify the process of separating molybdenum and technetium, based on their physical and chemical properties. Thus oxide technetium of the highest degree of oxidation boils at $310.5^{\circ}[5$, p.560], while molybdenum oxide only melts at $801^{\circ}$, and boils at $1155^{\circ}[6, \mathrm{p} .128 ; 7]$.

In this way you can try to reject technetium oxide (VII) from the molybdenum matrix. It is practically impossible to conduct such experiments with technetium as a result of its inaccessibility as a reagent, although to this day in the world it has reached almost 100 tons, and the half-life of technetium-99 is significant - 213 thousand years, but most of it is scattered in the environment.

\section{EVIDENCE OF THE CHEMICAL IDENTITY OF TECHNETIUM AND RHENIUM}

Rhenium and technetium have similar chemical properties, and therefore rhenium can be selected as a model element for investigating the possibility of separating technetium and molybdenum in various ways. We checked the extraction properties of rhenium under the conditions available in the extraction technetium generator.

To study the extraction in a $25 \mathrm{ml}$ flask, 0.25 to $2 \mathrm{ml}$ of rhenium solution $(10 \mathrm{mg} / \mathrm{l})+10 \mathrm{ml}$ of dispenser $\left(5 \mathrm{M} \mathrm{K}_{2} \mathrm{CO}_{3}\right)$ was added and water was added to the label, the rhenium solutions were identical to the standard used for calibrating the emission spectrometer. From the flask, the solutions were transferred to a separating funnel and extracted for 3 minutes two portions of MEK 5 and $15 \mathrm{ml}$ (in a to-

\footnotetext{
${ }^{*}$ Corresponding author E-mail address: bocharov@kipt.kharkov.ua
} 
tal of $20 \mathrm{ml}$ ). One sample was made with a single extraction of $20 \mathrm{ml}$.

After the phase separation, the MEK was evaporated, the dry residue was dissolved in $0.1 M$ nitric acid, transferred to a $25 \mathrm{ml}$ volumetric flask and analyzed on a Shimadzu-9000 spectrometer with an inductively coupled plasma. The results are given in the Table.

\section{Extraction of rhenium under the conditions of a technetium generator}

\begin{tabular}{|c|c|c|}
\hline $\begin{array}{c}\text { Initial } \\
\text { solutions of } \\
\text { rhenium, } m g / l\end{array}$ & $\begin{array}{c}\text { Received } \\
\text { rhenium, } \\
m g / l\end{array}$ & $\begin{array}{c}\% \text { rhenium } \\
\text { losses }\end{array}$ \\
\hline 0.1 & 0.09 & 10 \\
0.2 & 0.18 & 10 \\
0.4 & 0.35 & 12 \\
0.8 & 0.67 & 16 \\
0.8 single & 0.66 & 18 \\
extraction & & \\
\hline
\end{tabular}

It turns out that extraction with one portion of MEK in $20 \mathrm{ml}$ is also effective, as well as two in 5 and $15 \mathrm{ml}$. It has been shown that rhenium is well extracted by MEK, and its behavior is similar to the behavior of technetium. The boiling temperatures of technetium(VII) oxides $\left(310.5^{\circ}\right)$ and rhenium(VII) $\left(358.5^{\circ}\right)$ differ slightly, and therefore, rhenium can simulate distillation of technetium from solutions. Although rhenium consumes about 50 tons annually, it is available as a reagent. The attempts have been made to disperse technetium from the matrix of molybdenum oxide, even technology has been proposed, but for almost 20 years it has not been put into practice [8].

There is no data on the thermal stability of technetium oxide (VII) and it is possible that the melting point of molybdenum oxide undergoes a partial destruction of technetium oxide to form non-volatile lower oxides. We also conducted a preliminary study of the volatility of molybdenum at high temperatures.

In air at $750^{\circ}$, the molybdenum is noticeably oxidized, and the oxide is deposited on the walls of the furnace, and at $900^{\circ}$, it is rapidly oxidized and evaporated (sublimate), with molybdenum oxidation destructively acting on the refractory, the porcelain crucible scattered in the hands, and the furnace shell burst. This indicates that when the high-temperature dispersal is achieved, the technetium oxide is contaminated with molybdenum.

There are high-yielding inorganic rhenium compounds and molybdenum carbonyl $\mathrm{Re}_{2}(\mathrm{CO})_{10}$ and $M o(C O)_{6}$, but they are formed at a pressure of more than $20 \mathrm{MPa}[9, \mathrm{p} .376 ; 10]$. Given the difficulties associated with the selection of equipment and the difficulties in working in extreme conditions, it is nec- essary to find more soft conditions for the dispersal of molybdenum and rhenium. Previous work indicates that rhenium is distilled from solutions of high boiling acids $[11,12]$.

However, due to the imperfection of the equipment used for distillation, there is a partial transition of molybdenum into a rhenium storage device. The mechanism of the transition of molybdenum can be explained by splash movement, excretion of molybdenum-containing molecules at the expense of Brownian motion, as well as the fact that to increase the volatility of rhenium recommended supplements of hydrochloric acid.

In this case, volatile compounds of molybdenum oxychloride $\left(\mathrm{MoO}_{2} \mathrm{Cl}_{2}\right.$ and $\left.\mathrm{MoOCl}_{4}\right)$ are formed. It is noted that in the presence of phosphate ions molybdenum is more strongly contained in the solution, presumably due to the formation of multi-nucleus phosphate complexes [13]. In the monograph of Borisova and Ermakov [14] there was a decrease in the rhenium volatility with the increase of the amount of added sulfuric acid. They suggest an assumption of renaissance restoration and transferring it at the expense of this to a non-lethal compound. Since sulfuric acid at a concentration of about $80 \%$ at elevated temperature is a sufficiently strong oxidant, such a statement is doubtful, and maybe sulfuric acid or other reagents have some reducing agents. When dispensing technetium, the authors noted $[15,16]$ that the quantitative process passes only in the absence of reducing agents in the purge gas.

\section{EXPERIMENT ON RHENIUM DISTILLATION}

We conducted an experiment on rhenium distillation from solution. To $30 \mathrm{ml}$ of orthophosphoric acid in a Wurz flask was added $2 g$ of molybdenum dissolved in hydrogen peroxide (perhydrol) and $2 \mathrm{mg}$ of rhenium in the form of $2 \mathrm{ml}$ of rhenium solution (concentration $1 \mathrm{~g} / \mathrm{l}$ ) in nitric acid. To form an oxidizing medium, $2 g$ of manganese dioxide were added. The flask was heated on an electric furnace. The waste vapor was cooled in an air fridge.

Condensate was collected in a receiver with alkaline water. At the end of the distillation (4hours), the air freshener was washed with a weak ammonia solution, the washings were combined with the solution in the receiver. The concentration of rhenium in the combined solution was determined by the emission method, using standard solutions of rhenium in nitric acid for calibration of the spectrometer. The amount of rhenium discharged, which was previously exceeded in the flask, was calculated. The search for the cause of such a large amount of branchedout rhenium by determining it in all reagents led to the following conclusion: the oxide of molybdenum of the mark "hp" contains not less than $20 \mathrm{mg} / \mathrm{kg}$ of rhenium, and the molybdenum metal used for the manufacture of targets for the electron accelerator - not less than $30 \mathrm{mg} / \mathrm{kg}$. Thus, it turns out that 
with the development of molybdenum-99 on the electron accelerator and the separation of technetium, it is contaminated with rhenium, with the amount of rhenium several orders of magnitude exceeding the amount technetium. The amount of molybdenum in discharged rhenium was $4 \%$.

\section{CONCLUSIONS}

1. It has been proved that rhenium can substitute technetium for the study of the conditions for the separation of molybdenum and technetium, since rhenium oxide has practically the same temperature with boiling gas technetium oxide as well as the same extraction properties.

2. Rhenium oxide may be distilled from solutions of phosphoric acid separately from molybdenum.

3. It is necessary to improve the technology of rhenium distillation to reduce the concentration of molybdenum in distillation

\section{References}

1. Harmful chemicals. Radioactive substances. L.: "Chemistry", 1990, 463 p.

2. Isotopes, properites, receipt, application v.II. M.: "Fizmatlit", 2005, 727 p.

3. M.G. Davidov, S.A. Mareskin. About possibility of receiving of ${ }^{99} \mathrm{Mo}$ and ${ }^{99 m} \mathrm{Tc}$ by electron accelerators// Radiochemistry. 1993, v.35, N5, p.9196.

4. G.E. Dale, S.D. Chemerisov, G.F. Vandergrift, et al. Desin and experimental activities supporting commercial U.S. electron accelerator production of Mo-99 // Application of accelerator in research and industry. AIP conf. Proc. 2013, v.1525, p.335-339.
5. Chemical encyclopedia. M.: "Great Russian encyclopedia". 1995, v.4, p.639 p.

6. Ibidem, v.3, 639 p.

7. A.N.Zelikhman. Molibdenum. M.: "Metallurgiya", 1970, $440 \mathrm{p}$.

8. R.G. Bennett, J.D.Christian, D.A. Petti, W.K. Terry, S.B. Grover. A system of $99 \mathrm{mTc}$ production based on distributed electron accelerators and thermal separation // Nuclear Technology. 1999, v.126, p.102-121.

9. H. Remi. The course of inorganic chemistry. M.: "Mir", 1966, v.2, 836 p.

10. F. Cotton, G. Wilkinson. Modern inorganic chemistry. M.: "Mir", 1969, v.3, 592 p.

11. J.I.Hoffman, G.E.F. Lundell. Volatilisation of metallic compounds from solutions in perchloric or sulfuric acid // J. Research. NBS. 1939, v.22, p.465-470.

12. C.F. Hiskey, V.W. Meloche. Determination of rhenium in molybdenite minerals // Ind. Eng. Chem. 1940, v.12, N9, p.503-506.

13. N. Jordanov, M. Pavlova. Beitrag zur Rheniumtrennung durch Destillation // Microchim. Acta. 1963, N3, p.477-480.

14. L.V. Borisova, A.N. Yermakov. Rhenium analytical chemistry. M.: "Nauka", 1974, 319 p.

15. L.L. Zajtseva, A.V. Velichko, I.V. Vinogradov. Compounds of technetium and the area of their application // Results of science and technology, inorganic chemistry series. M.: "VINITI", 1984, v.9, $120 \mathrm{p}$.

16. V.I.Spicyn, A.F. Kuzina. Technetium. M.: "Nauka", 1981, 148 p. (in Russian).

\title{
ИЗУЧЕНИЕ ВОЗМОЖНОСТИ ОТГОНКИ ТЕХНЕЦИЯ ИЗ МОЛИБДЕНОВЫХ РАСТВОРОВ НА ПРИМЕРЕ РЕНИЯ
}

\author{
А. И. Азаров, В. А. Бочаров, А.Ф. Стоянов
}

Для исследования процессов разделения молибдена и технеция использован рений, который имеет близкие к технецию химические свойства. Рационально разделение молибдена и технеция посредством дистилляции .

\section{ВИВЧЕННЯ МОЖЛИВОСТІ ВІДГОНУ ТЕХНЕЦІЮ З МОЛІБДЕНОВИХ РОЗЧИНІВ НА ПРИКЛАДІ РЕНІЮ}

\author{
О. І. Азаров, В. О. Бочаров, О.Ф.Стоянов
}

Для вивчення процесів розділення молібдену та технецію використано реній, який має близькі до технецію хімічні властивості. Раціональним є розділення молібдену та технецію шляхом дистиляції. 